\title{
Potato sprouts as a potential source of solanidine glycoalkaloids for nutritional studies
}

\author{
A. Tuśnio ${ }^{1,3}$, M. Taciak ${ }^{1}$, C. Trawczyński ${ }^{2}$, M. Barszcz ${ }^{1}$, J. Skomiał ${ }^{1}$ and B. Pastuszewska ${ }^{1}$ \\ ${ }^{1}$ The Kielanowski Institute of Animal Physiology and Nutrition, Polish Academy of Sciences \\ 05-110 Jabłonna, Poland \\ ${ }^{2}$ Plant Breeding and Acclimatization Institute, Jadwisin, 05-140 Serock, Poland
}

KEY WORDS: potato sprouts, a-solanine, a-chaconine, trypsin inhibitor

Received: 28 August 2013

Revised: 1 October 2013

Accepted: 15 October 2013

${ }^{3}$ Corresponding author:

e-mail: a.tusnio@ifzz.pan.pl

\begin{abstract}
The high price of pure forms of solanidine glycoalkaloids (GA) impedes their use in studies on the effects and safety levels of GA for farm animals. An attempt was made to take advantage of the high concentration of GA in potato sprouts and to evaluate them as a potential source of these compounds for nutritional experiments. Over a period of two years, two batches of sprouts were collected from potatoes prepared for planting, dried, and analysed for a-solanine (S), a-chaconine ( $\mathrm{CH}$ ), and nutrient contents, as well as trypsin inhibitor activity (TIA). The concentrations of $S$ were $10.52 \mathrm{mg}$ and $8.88 \mathrm{mg} \cdot \mathrm{g}^{-1}$ and of $\mathrm{CH}, 22.67$ and $18.70 \mathrm{mg} \cdot \mathrm{g}^{-1}$ of dried sprouts in batch 1 and batch 2, respectively. The proportions of chaconine and solanine in both batches were uniform and amounted to $68 \%$ and $32 \%$ of the sum. The chemical composition of two batches was similar except for crude fibre content, which was $3.01 \%$ and $9.46 \%$ in batch 1 and batch 2, respectively. TIA was low and uniform $\left(0.41 \mathrm{mg} \cdot \mathrm{g}^{-1}\right)$.
\end{abstract}

\section{Introduction}

Potato protein concentrate (PPC) is a by-product of the potato starch industry and is considered to be a valuable plant protein that can be used in the feeding of animals, including pigs (Kerr et al., 1998; Sardi et al., 2005), poultry (Palliyeguru et al., 2010; Fernando et al., 2011), and fish (Refstie and Tiekstra, 2003; Tusche et al., 2011). The PPC levels in practical diets are rather low because depression of feed intake, growth performance, and protein digestibility attributed to solanidine glycoalkaloids (GA) was occasionally observed at higher inclusion rates. The assumption of the negative effect of GA rests on the better performance of animals fed on PPC processed for low GA content (Kerr et al.,
1998; Refstie and Tiekstra, 2003), but approximation of the upper acceptable levels of these compounds in diets for different species and categories of farm animals, particularly for pigs and chickens, has not been proposed until now. Such approximations are needed in view of the great variability of the GA content in PPC produced under regular industrial conditions (Pastuszewska et al., 2009).

The major GA in potatoes are $\alpha$-solanine and $\alpha$-chaconine (Friedman et al., 1997), which constitute about $95 \%$ of the total GA content. The structure, modes of action in the organism, and factors affecting GA levels in potato tubers have been extensively studied due to their toxicity observed in humans (Smith et al., 1996; Nema et al., 2008). These experiments were performed, 
however, mainly on small laboratory animals (mice, rats, hamsters) either treated with pure forms of solanine and/or chaconine or fed diets supplemented with these alkaloids. No experiments have been done on farm animals, but it is clear that such studies require much greater amounts of these very expensive compounds. This constraint was faced in the experiments with young pigs (Tuśnio et al., 2011) and chickens (Tuśnio et al., 2013) in which PPCs with different GA contents were used. Moreover, the design of the experiments concerning GA should allow assessing not only their effects when given as the only antinutrients, but also their likely interactions with other factors, e.g. potato trypsin inhibitor (Lee et al., 1985) or unidentified factors increasing the incidence of necrotic enteritis and Clostridium perfringens infections in chickens fed PPC (Wilkie et al., 2005; Palliyeguru et al., 2010; Fernando et al., 2011).

Therefore, an attempt was made to obtain a highly concentrated source of GA in the form of potato sprouts, which are the most GA-abundant part of the potato plant (Nema et al., 2008). The objective of this study was to assess whether potato sprouts from potato tubers of heterogeneous varietal composition have sufficiently high contents of the glycoalkaloids $\alpha$-solanine and $\alpha$-chaconine to be used in experimental diets for farm animals.

\section{Material and methods}

Two batches of potato sprouts were provided by the Institute of Plant Breeding and Acclimatization in Jadwisin (Poland) as material harvested from tubers before planting. The tubers were sprouting after about seven months of storage in a dark room with regulated temperature and humidity. The sprouts were picked manually, placed on trays and dried at a temperature of $60^{\circ} \mathrm{C}$ in a drying chamber with forced ventilation. Dried sprouts were milled using a laboratory grinder. The analysed material comprised sprouts collected in two different years (batch 1 and batch 2 , respectively) from tubers representing a number of potato varieties tested at the Institute.

Dried sprouts were analysed for dry matter, crude protein, crude fibre, ash and crude fat according to AOAC (2000).

HPLC as described by Pęksa et al. (2002) was used to analyse $\alpha$-solanine and $\alpha$-chaconine contents. Trypsin inhibitor activity was determined using the method of Kakade et al. (1974) and expressed as milligrams of pure trypsin inactivated by $1 \mathrm{~g}$ of dried potato sprouts.

\section{Results and discussion}

The overall GA content of the dried sprouts calculated as the sum of $\alpha$-solanine and $\alpha$-chaconine, was very high and was higher in batch 1 than in batch 2: 33.19 and $27.58 \mathrm{mg} \cdot \mathrm{g}^{-1}$, respectively (Table 1). These values fall into the range of $2.00-7.30 \mathrm{mg} \cdot \mathrm{g}^{-1}$ of fresh material as reported by Nema et al. (2008).

The difference between GA concentration in sprouts collected as the two distinct batches may be probably ascribed to a more advanced growth of sprouts harvested as batch 2 . This assumption is based on a slightly greater ash $(9.78 \%$ vs $8.83 \%)$ and considerably greater fibre $(9.46 \%$ vs $3.01 \%)$ contents of sprouts from batch 2 than batch 1 (Table 2), which may imply a more advanced formation of leaves and stems which contain considerably less GA than sprouts was more advances (Nema et al., 2008). This difference points to the importance of the stage of sprout growth as a potential factor affecting GA concentration in the obtained material, however, other factors cannot be excluded. The GA content in potato tubers is greatly variable and depends on cultivar, environmental and growing conditions in the field, harvesting and storage conditions (Friedman et al., 1997). In our study the sprouts were collected from potatoes grown in two different years and represented a variety of cultivars, therefore, differences in the GA contents in tubers were possible.

In spite of differences in $\alpha$-solanine and $\alpha$-chaconine contents between the two batches, their proportions were similar: $\alpha$-solanine amounted to $32 \%$ and $\alpha$-chaconine, to $68 \%$ of the sum. This ratio is near the range between 1:7 and 1:2 found in most studies, depending on potato variety and part of the potato plant (Nema et al., 2008).

Table 1. Solanidine glycoalkaloids content and trypsin inhibitor activity of dried potato sprouts

\begin{tabular}{lcc}
\hline Indices & Batch 1 & Batch 2 \\
\hline a-chaconine, $\mathrm{mg} \cdot \mathrm{g}^{-1}$ & 22.67 & 18.70 \\
a-solanine $\mathrm{mg} \cdot \mathrm{g}^{-1}$ & 10.52 & 8.88 \\
Sum of glycoalkaloids, $\mathrm{mg} \cdot \mathrm{g}^{-1}$ & 33.19 & 27.58 \\
Proportion of chaconine:solanine & $2: 1$ & $2: 1$ \\
Trypsin inhibitor activity, $\mathrm{mg} \cdot \mathrm{g}^{-1}$ & 0.41 & 0.41 \\
\hline
\end{tabular}

Table 2. Chemical composition of dried potato sprouts, $\%$

\begin{tabular}{llllll}
\hline Material & $\begin{array}{l}\text { Dry } \\
\text { matter }\end{array}$ & $\begin{array}{l}\text { Crude } \\
\text { ash }\end{array}$ & $\begin{array}{l}\text { Crude } \\
\text { protein }\end{array}$ & $\begin{array}{l}\text { Ether } \\
\text { extract }\end{array}$ & $\begin{array}{l}\text { Crude } \\
\text { fibre }\end{array}$ \\
\hline Batch 1 & 89.90 & 8.83 & 15.19 & 0.83 & 3.01 \\
Batch 2 & 89.61 & 9.78 & 15.31 & 0.97 & 9.46 \\
\hline
\end{tabular}


When comparing the sum of the chaconine and solanine contents of sprouts found in our study with the total GA content in potato protein concentrates determined by the colorimetric method of Bergers (1980), it appears that in our study the sprouts contained about twelve times more GA than concentrates with the highest content $\left(2.6 \mathrm{mg} \mathrm{GA} \cdot \mathrm{g}^{-1}\right)$ of these compounds (Pastuszewska et al., 2009) and also than the so-called 'standard' concentrate containing about $2.50 \mathrm{mg} \mathrm{GA} \cdot \mathrm{g}^{-1}$ (Refstie and Tiekstra, 2003). In contrast, the trypsin inhibitor activity of sprouts $\left(0.41 \mathrm{mg} \cdot \mathrm{g}^{-1}\right)$ was considerably lower than the range of 0.97 to $3.70 \mathrm{mg} \cdot \mathrm{g}^{-1}$ reported for PPCs by Pastuszewska et al. (2009). This means that dried potato sprouts are a suitable material that can be used as a source of glycoalkaloids without the interfering effects of trypsin inhibition and modification of nutrient content. It may be useful in approximation of the GA levels tolerated by farm animals, particularly when the experimental design involving graded dietary levels, longer period of feeding, and greater number of animals, is recommended.

\section{Conclusions}

It is concluded that due to the high concentration of glycoalkaloids (GA), dried potato sprouts may be considered a source of these compounds for use in feeding experiments with animals, allowing for a wide differentiation of dietary GA levels without affecting nutrient contents or trypsin inhibitor activity.

\section{Acknowledgements}

The authors would like to thank Professor Anna Pęksa for the assistance with the glycoalkaloid analyses.

\section{References}

AOAC, 2000. Association of Official Analytical Chemists, Official Methods of Analysis. $17^{\text {th }}$ Edition. Arlington, VA

Bergers W.W.A., 1980. A rapid quantitative assay for solanidine glycoalkaloids in potatoes and industrial potato protein. Potato Res. 23, 105-110

Fernando P.S., Rose S.P., Mackenzie A.M., Silva S.S.P., 2011. Effects of diets containing potato protein or soya bean meal on the incidence of spontaneously-occurring subclinical necrotic enteritis and the physiological response in broiler chickens. Brit. Poultry Sci. 52, 106-114
Friedman M., McDonald G.M., Filadelfi-Keszi M.A., 1997. Potato glycoalkaloids: Chemistry, analysis, safety, and plant physiology. Crit. Rev. Plant Sci. 16, 55-132

Kakade M.L., Rackis J.J., McGhee J.E., Puski G., 1974. Determination of trypsin inhibitor activity of soy products: A collaborative analysis of an improved procedure. Cereal Chem. 51, 376-382

Kerr C.A., Goodband R.D., Smith J.W., Musser R.E., Bergstrom J.R., Nessmith W.B., Tokach M.D., Nelssen J.L., 1998. Evaluation of potato proteins on the growth performance of early-weaned pigs. J. Anim. Sci. 76, 3024-3033

Lee S.S., Liener I.E., Desborough S., 1985. Comparative effects of feeding a protease inhibitor enriched potato protein concentrate and soy flour to rats. Plant Food Hum. Nutr. 35, 9-19

Nema P.K., Ramayya N., Duncan E., Niranjan K., 2008. Potato glycoalkaloids: formation and strategies for mitigation. J. Sci. Food Agr. 88, 1869-1881

Palliyeguru M.W.C.D., Rose S.P., Mackenzie A.M., 2010. Effect of dietary protein concentrates on the incidence of subclinical necrotic enteritis and growth performance of broiler chickens. Poultry Sci. 89, 34-43

Pastuszewska B., Taciak M., Tuśnio A., Mazurczyk W., 2009. Variability in the composition of potato protein concentrates produced in different starch factories. A preliminary survey. Anim. Feed Sci. Tech. 154, 260-264

Pęksa A., Gołubowska G., Rytel E., Lisińska G., Aniołowski K., 2002. Influence of harvest date on glycoalkaloid contents of three potato varietes. Food Chem. 78, 313-317

Refstie S., Tiekstra H.A.J., 2003. Potato protein concentrate with low content of solanidine glycoalkaloids in diets for Atlantic salmon (Salmo salar). Aquaculture 216, 283-298

Sardi L., Paganelli R., Parisini P., Simioli M., Martelli G., 2005. The replacement of fishmeal by plant proteins in piglet production. Ital. J. Anim. Sci. 4, Suppl. 2, 449-451

Smith D.B., Roddick J.G., Leighton Jones J., 1996. Potato glycoalkaloids: Some unanswered questions. Trends Food Sci. Technol. 7, 126-131

Tusche K., Wuertz S., Susenbeth A., Schulz C., 2011. Feeding fish according to organic aquaculture guidelines EC 710/2009: Influence of potato protein concentrates containing varoius glycoalkaloid levels on health status and growth performance of rainbow trout (Oncorhynchus mykiss). Aquaculture 319, 122-131

Tuśnio A., Pastuszewska B., Święch E., Taciak M., 2011. Response of young pigs to feeding potato protein and potato fibre - nutritional, physiological and biochemical parameters. J. Anim. Feed Sci. 20, 361-378

Tuśnio A., Pastuszewska B., Taciak M., Mieczkowska A., Smulikowska S., 2013. Response of growing chicken to potato protein concentrates providing different amounts of solanidine glycoalkaloids and trypsin inhibitor. Arch. Geflügelk. 77, $51-58$

Wilkie D.C., Van Kessel A.G., White L.J., Laarveld B., Drew M.D., 2005. Dietary amino acids affect intestinal Clostridium perfringens populations in broiler chickens. Can. J. Anim. Sci. 85, 185-193 